Бурдик О. Ю., olenatka@ukr.net, ORCID ID:0000-0002-3002-7672, аспірантка, Львівський торговельно-економічний університет, Львів

\title{
АВТОБУСНІ ПАСАЖИРСЬКІ ПЕРЕВЕЗЕННЯ ТА ЇХ ВПЛИВ НА ФІНАНСОВІ РЕЗУЛЬТАТИ АВТОГОСПОДАРСТВ
}

\begin{abstract}
Анотація. У статті охарактеризовано міські автобусні пасажирські перевезення та досліджено їх вплив на фінансові результати діяльності автогосподарств. Важливим є огляд иієї теми у розрізі перевезень пасажирів в Україні громадським транспортом із зазначенням частки у них автоперевезень. Визначено зміни в темпах зростання пасажирських перевезень за досліджувані роки. Описано особливості діяльності автотранспорту за кордоном. Також розраховано динаміку перевезень пасажирів автомобільним транспортом міського сполучення, розглянуто перевезення у Західному регіоні Украӥни. Метою статті є співставлення статистичних даних для виявлення причин збитковості перевезень та пошуку шляхів стабілізачії їх фінансового стану. У ході дослідження встановлено, щчо збитковість перевезень зумовлена насамперед неякісними перевезеннями, внаслідок чого багато пасажирів користуються або більш дешевим міським електротранспортом, або таксі чи власним автомобілем. Зауважено, що спосіб покращити фінансовий стан автотранспортних підприємств за рахунок підняття тарифів не дав очікуваних результатів. Незважаючи на регулярне підвищення плати за проїзд, діяльність автотранспортних підприємств так $і$ залишається збитковою, а умови перевезень пасажирів й надалі здійснюються на низькому рівні. До того ж, відсутність комфортабельності та сервісу додатково провокує зменшення попиту на користування пасажирськими автоперевезеннями. Тому необхідний терміновий перегляд основних підходів до стратегії розвитку автотранспортних підприємств, застосування кардинальних змін їх діяльності, а отже і запровадження відповідних змін у веденні бухгалтерського обліку. Також постає питання щяодо неповного відшкодування плати за проїзд пільгових категорій громадян. Відповідно до здійснених досліджень зроблено висновок, щзо необхідно переглянути основні законодавчі документи стосовно автотранспорту, з урахуванням закордонного досвіду країн, та відобразити иі зміни у фінансовому обліку. Забезпечення автотранспорту інноваційними технологіями сприятиме розширенню внутрішньогосподарської звітності, щзо дуже важливо для прийняття управлінських рішень. До того ж, дані нововведення дадуть можливість здійснити контроль за фактичним використанням паливномастильних матеріалів та скорегувати встановлені на них норми.
\end{abstract}

Ключові слова: автотранспортне підприємство, автомобільний транспорт, міські перевезення, пасажирооборот, оплата за проїзд, доходи, витрати, фінансові результати.

Burdyk O. Yu., olenatka@ukr.net, ORCID ID:0000-0002-3002-7672, Postgraduate, Lviv University of Trade and Economics, Lviv

\section{BUS PASSENGER TRANSPORTATION AND ITS IMPACT ON FINANCIAL RESULTS OF AUTO COMPANIES}

\begin{abstract}
The article characterized urban bus passenger transportation and examines its impact on the financial performance of auto companies. It is important to review this topic in terms of passenger transportation in Ukraine by public transport, indicating the share of road transport. Changes in the growth rates of passenger transportation for the studied years are determined. Features of auto companies activity abroad are revealed. The dynamics of passenger transportation by urban road transport is also calculated as well as transportation in the Western region of Ukraine is considered. The purpose of the article is to compare statistics for identification the causes of unprofitable transportation and find ways to stabilize its financial condition. The study found that unprofitability of transportation is primarily due to the poor quality of service, as a result of which many passengers use either cheaper urban electric transport, taxi or own car. It is noted that the way to improve the financial condition of auto companies by raising prices did not give the expected results. Despite the regular price increase, the activities of road transport companies remain unprofitable, and passenger transportation further carried out at a low level. In addition, the lack of comfort and proper service further provokes a decrease in demand for the use of passenger road transport. Therefore, it is necessary to urgently review the main approaches to the development strategy of auto companies, the application of radical changes in their activities, and hence the introduction of appropriate changes in accounting. The issue also arises of incomplete reimbursement of tolls for transportation of privileged categories of passengers. According to the research, it was concluded that it is necessary to revise the main legislative documents on road transport, taking into account the foreign expe-
\end{abstract}


rience and to reflect these changes in financial accounting. Providing road transport with innovative technologies will contribute for expanding internal reporting that is very important for managerial decision taking. In addition, these innovations will give the opportunity to monitor the actual use of auto fuels and lubricants and adjust the standards set for them.

Key words: auto transport company, auto transport, urban transportations, passenger turnover, fare, income, expenses, financial results.

\section{JEL Classification: M41 \\ DOI: https://doi.org/10.36477/2522-1205-2020-60-14}

Постановка проблеми. Діяльність пасажирського автотранспорту протягом останніх років характеризується рядом невирішених проблем, а саме: збиткова діяльність попри збільшення попиту на пасажирські перевезення, незадовільні умови перевезень пасажирів, досить часте підняття вартості за проїзд. Незважаючи на намагання суб'єктами господарювання покращити ситуацію, названі проблеми до цього часу залишаються невирішеними.

Аналіз останніх досліджень і публікацій. Проблемі раціонального функціонування міського пасажирського транспорту та методиці й організації обліку і контролю в автогосподарствах приділяли увагу такі вітчизняні й зарубіжні вчені: О. А. Антонечко, П. Й. Атамас, І. О. Башинська, М. Т. Білуха, Ф. Ф. Бутинець, А. І. Верховський, С. Ф. Голов, К. В. Гнедіна, Й. Я. Даньків, В. П. Завгородній, О. М. Криворучко, І. В. Лисенко, М. Я. Остап'юк, Д. С. Примак, В. В. Сопко, Н. М. Ткаченко, Я. В. Шевчук, В. Г. Шинкаренко та інші. Однак, незважаючи на цінність досліджень цих авторів та враховуючи зростаючі потреби населення у послугах міського пасажирського автотранспорту, дана проблема потребує подальшого дослідження у взаємозв'язку з формуванням фінансових результатів автогосподарств.

Постановка завдання. Метою статті $\epsilon$ дослідження обсягів перевезень міським пасажирським автотранспортом в Україні, проведення аналізу перевезень даним видом транспорту в розрізі областей Західного регіону України з метою виявлення причин збитковості перевезень i шляхів збільшення їх прибутковості та покращення фінансового стану.

Виклад основного матеріалу дослідження. Кожне місто хотіло б мати комфортабельний, швидкий та водночас екологічний і безпечний пасажирський транспорт, а цього можна досягти лише за умови достатньої прибутковості підприємств, що здійснюють пасажирські перевезення. Намагання підприємств покращити свій фінансовий стан за рахунок підняття тарифів не дає очікуваних результатів, оскільки ї діяльність так і залишається збитковою, а умови перевезення пасажирів і надалі здійснюються у переважній більшості випадків 3 відсутністю належної комфортабельності та сучасного сервісу. Тому, на наш погляд, необхідним є перегляд основних підходів до стратегії розвитку автотранспортних підприємств із застосуванням кардинальних змін у їхній діяльності.

Враховуючи ситуацію, що є характерною для пасажирських перевезень в Україні, розглянемо тенденцію змін у пасажиропотоках, які відбулися протягом 2014-2018 років у міських перевезеннях у розрізі окремих видів громадського транспорту (табл. 1).

Табличяя 1

Перевезення пасажирів за внутрішньоміським сполученням окремими видами транспорту у 2014-2018 рр.*

\begin{tabular}{|c|c|c|c|c|c|c|}
\hline \multirow{2}{*}{$\begin{array}{c}\text { Види } \\
\text { транспорту }\end{array}$} & \multicolumn{7}{|c|}{ Роки } & $\begin{array}{c}\text { 3міни у } \\
2018 \text { р. до } \\
2014 \text { р. }\end{array}$ \\
\cline { 2 - 7 } & 2014 & 2015 & 2016 & 2017 & 2018 & 6 \\
\hline А & 1 & 2 & 3 & 4 & 5 & -808 \\
Автобус & $\begin{array}{c}2244 \\
(46,4 \%)\end{array}$ & $\begin{array}{c}1666 \\
(39,8 \%)\end{array}$ & $\begin{array}{c}1494 \\
(38,0 \%)\end{array}$ & $\begin{array}{c}1501 \\
(38,0 \%)\end{array}$ & $\begin{array}{c}1436 \\
(37,3 \%)\end{array}$ \\
\hline Тролейбус & $\begin{array}{c}1097 \\
(22,7 \%)\end{array}$ & $\begin{array}{c}1081 \\
(25,8 \%)\end{array}$ & $\begin{array}{c}1039 \\
(26,5)\end{array}$ & $\begin{array}{c}1058 \\
(26,7)\end{array}$ & $\begin{array}{c}1016 \\
(26,4 \%)\end{array}$ & $\begin{array}{c}-81 \\
(-7,4 \%)\end{array}$ \\
\hline Трамвай & $\begin{array}{c}770 \\
(15,9 \%)\end{array}$ & $\begin{array}{c}739 \\
(17,7 \%)\end{array}$ & $\begin{array}{c}694 \\
(17,7 \%)\end{array}$ & $\begin{array}{c}676 \\
(17,1 \%)\end{array}$ & $\begin{array}{c}666 \\
(17,4 \%)\end{array}$ & $\begin{array}{c}-104 \\
(-13,5 \%)\end{array}$ \\
\hline Метрополітен & $\begin{array}{c}726 \\
(15,0 \%)\end{array}$ & $\begin{array}{c}700 \\
(16,7 \%)\end{array}$ & $\begin{array}{c}698 \\
(17,8 \%)\end{array}$ & $\begin{array}{c}719 \\
(18,2 \%)\end{array}$ & $\begin{array}{c}727 \\
(18,9 \%)\end{array}$ & $\begin{array}{c}+1 \\
(+0,1 \%)\end{array}$ \\
\hline Разом & $\begin{array}{c}4837 \\
(100 \%)\end{array}$ & $\begin{array}{c}4186 \\
(100 \%)\end{array}$ & $\begin{array}{c}3925 \\
(100 \%)\end{array}$ & $\begin{array}{c}3954 \\
(100 \%)\end{array}$ & $\begin{array}{c}3845 \\
(100 \%)\end{array}$ & $\begin{array}{c}-992 \\
(-20,5 \%)\end{array}$ \\
\hline
\end{tabular}

*Розраховано за даними [5, с. 57$]$ 
Таблиця 2

Перевезення пасажирів автобусами міського сполучення в розрізі областей Західного регіону України у 2014-2018 pp.*

\begin{tabular}{|c|c|c|c|c|c|c|}
\hline \multirow{2}{*}{$\begin{array}{c}\text { Західні регіони України в } \\
\text { розрізі областей }\end{array}$} & \multicolumn{5}{|c|}{ Роки } & \multirow{2}{*}{$\begin{array}{l}\text { Зміни у } 2018 \text { p. } \\
\text { до } 2014 \text { p. }\end{array}$} \\
\hline & 2014 & 2015 & 2016 & 2017 & 2018 & \\
\hline $\mathrm{A}$ & 1 & 2 & 3 & 4 & 5 & 6 \\
\hline $\begin{array}{l}\text { Західні регіони України, } \\
\text { у тому числі: }\end{array}$ & 355,7 & 330,7 & 282,1 & 295,1 & 284,6 & $\begin{array}{c}-71,1 \\
(-20 \%)\end{array}$ \\
\hline Волинська & 43,6 & 41,6 & 40,6 & 34,4 & 31,3 & $\begin{array}{c}-12,3 \\
(-28,2 \%)\end{array}$ \\
\hline Закарпатська & 20,2 & 21,5 & 19,6 & 17,9 & 16,7 & $\begin{array}{c}-3,5 \\
(-17,3 \%) \\
\end{array}$ \\
\hline Івано-Франківська & 52,7 & 51,9 & 34,0 & 36,5 & 39,7 & $\begin{array}{c}-13 \\
(-24,7 \%)\end{array}$ \\
\hline Львівська & 114,4 & 98,9 & 83,4 & 82,3 & 83,5 & $\begin{array}{c}-30,9 \\
(-27,0 \%)\end{array}$ \\
\hline Рівненська & 68,0 & 62,6 & 55,8 & 74,0 & 67,6 & $\begin{array}{c}-0,4 \\
(-0,6 \%)\end{array}$ \\
\hline Тернопільська & 36,4 & 32,5 & 30,1 & 27,3 & 24,7 & $\begin{array}{c}-11,7 \\
(-32,1 \%)\end{array}$ \\
\hline Чернівецька & 20,4 & 21,7 & 18,6 & 22,7 & 21,1 & $+0,7(+3,4 \%)$ \\
\hline
\end{tabular}

*Розраховано за даними [5, с. 63]

3 наведених даних видно, що автомобільний транспорт у структурі пасажирських перевезень посідає перше місце. Перевезення пасажирів тролейбусом займає друге місце, трамвай i метрополітен знаходяться практично на одному рівні. Лише з 2016 по 2018 рік пасажиропотік метрополітену почав випереджати перевезення пасажирів трамваєм, але, як бачимо 3 даних, наведених у табл. 1, збільшення є незначним.

У цілому в Україні з 2014 по 2018 роки зменшилися пасажиропотоки за всіма видами міського транспорту на 20,5\% (з 4837 до 3845 млн пасажирів). Зменшення пасажиропотоків є характерним майже для всіх видів транспорту, крім метрополітену. Але найбільше зменшення перевезень пасажирів торкнулося автобусів: з 2244 млн пасажирів у 2014 році до 1436 у 2018 році, або на 36\%, що становить 808 млн пасажирів.

Враховуючи те, що конкретним об’єктом нашого дослідження є автобусні перевезення у Західному регіоні України, розглянемо зміну пасажиропотоків у розрізі семи областей за період з 2014 по 2018 роки (табл. 2). Наведені дані свідчать про те, що найбільше пасажирських автобусних перевезень здійснюється у Львівській та Рівненській областях. Проте спостерігається картина суттєвого зменшення пасажиропотоків, як у цілому по Західному регіону України на 71,1 млн пасажирів, або на 20\%, так і в переважній кількості областей (Волинській, Закарпатській, Івано-Франківській, Львівській, Тернопільській), за виключенням лише Чернівецької області, де спостерігаємо зростання пасажиропотоку на 3,4\%, що становить 700 тисяч. У Рівненській області також відбулося зменшення пасажиропотоку на 400 тис., але це становить лише 0,6\% для масштабів Рівненської області, що є, беззаперечно, негативним показником. Дані, наведені в табл. 2, у цілому свідчать про зниження обсягів пасажирських перевезень у Львівській області 3 2014 по 2018 рр. на 27\% (на 30,9 млн пасажирів).

Спад перевезень усіма видами міського пасажирського транспорту в Україні (табл. 1) і автобусами в Західному регіоні (табл. 2), зокрема, пов'язаний із суттєвим скороченням населення України. Так, станом на 01.01.2014 року кількість населення в Україні становила 45 426,2 тис. осіб, а на 01.01.2018 року вже 42386,4 тис. осіб. Тобто за останніх п'ять років вона зменшилася на 3039,8 тис. осіб, або на 6,7\% [1]. Такі негативні демографічні зміни зумовлені рядом факторів: економічними, політичними і соціальними, що спричинили суттєве зменшення народжуваності, збільшення передчасної смертності та масову міграцію населення в пошуках роботи 3 достойним рівнем оплати праці.

На кількість перевезень пасажирів автобусами та іншими видами міського пасажирського транспорту негативно вплинуло також суттєве збільшення приватного легкового автотранспорту, яким користуються “потенційні” пасажири автобусів. Збільшення ж кількості приватного автотранспорту ускладнило життя містян та завдає безпрецедентну шкоду навколишньому середовищу і здоров'ю людей через забруднення повітря вихлопними газами. Крім того, багато громадян надають перевагу більш дешевому електротранспорту (трамваям, тролейбусам, метро). 
В той же час у багатьох європейських містах сьогодні умови перевезення пасажирів автобусами $\epsilon$ набагато комфортнішими, застосовуються електронні квитки, практикується введення безкоштовного проїзду і нашим завданням є напрацювання рекомендацій, направлених на запровадження кращого закордонного досвіду з організації автобусних перевезень в Україні.

У багатьох країнах світу перевезення пасажирів здійснюють автотранспортні підприємства, що належать до різних форм власності: державної (комунальної, муніципальної) та приватної. Це дає змогу органам самоврядування обирати якісних перевізників, які мають можливість відповідати критеріям як на законодавчому, так і на споживчому рівні.

Важливою проблемою в Україні до цього часу залишається оплата проїзду в автобусах, хоч і $є$ вже достатньо прикладів 3 вирішення цього питання за кордоном та в окремих містах. Так, паралельно 3 електронними квитками існують квитки, які необхідно закомпостувати у транспортному засобі. Способи купівлі таких квитків різноманітні: від купівлі у спеціально відведених місцях до купівлі у водія автобусу, але ціна квитка в такому випадку буде дорожчою.

Електронні ж квитки для проїзду в автобусах реалізують здебільшого на зупинках громадського автотранспорту, онлайн на спеціальному сайті та у мобільному додатку. Для студентів введена спрощена система оплати за проїзд. Студентські квитки містять електронний чіп, завдяки чому їх можна поповнювати. В багатьох містах $є$ спеціальні картки за проїзд для туристів, у вартість яких входить ще й вартість входу до музеїв міста, що збільшує додаткові надходження коштів до місцевого бюджету.

Таким чином, перейнявши закордонний досвід, вітчизняні фахівці пропонують різні варіанти розвитку пасажирських автоперевезень в Україні. Наприклад, одним із варіантів стратегії розвитку пасажирського автотранспорту в містах України вважають перехід на Західно-Свропейську систему розвитку міст "Smart City". Так, I. О. Башинська вважає, що "якісного “стрибка" у транспортній сфері можна досягнути за рахунок використання нових технологій забезпечення процесів перевезень, відповідних сучасним вимогам і високим міжнародним стандартам, зокрема, шляхом використання смарт-інновацій” [8, с. 6], з чим ми повністю погоджуємося. На сьогоднішній день важливим $€$ використання GPS-трекерів, які активно застосовують на автотранспорті. Необхідним $є$ введення мобільних систем для відеоспостереження у міському автотранспорті та встановлення тривожної кнопки, що сприятиме безпеці та комфортабельності перевезень пасажирів. Також I. В. Абрамова та Ю. С. Мельник пропонують "модернізувати транспортну мережу у містах України 3 урахуванням досвіду Свропейських країн, де роботу громадського пасажирського транспорту забезпечують Центри транспортних перевезень, які задовольняють потреби населення у якісних та еко- номічно обгрунтованих транспортних послугах" [6, c. 95], П. А. Овчар вважає, що потрібно провести реформи та внести зміни до законодавства, “що призведе до підвищення ефективності, безпечності та соціальних стандартів діяльності автомобільного транспорту з використанням провідних практик держав-членів ЄC" $[10$, с. 205]. Пропозиція є цілком логічною, оскільки вважаємо, що Закон України “Про транспорт” від 10.11.1994 р. № 232/94-ВР [2], Закон України "Про автомобільний транспорт" від 05.04.2001 p. № 2344-III [3] потребують змін своєї редакції.

Заслуговує на увагу та підтримку пропозиція А. В. Базилюк та О. І. Малишкіна стосовно витрат: “щоб проконтролювати витрати, підприємства мають право встановлювати порядок контролю, 3 дотриманням затверджених типових норм витрачання ресурсів, оскільки вони вважаються найбільш обгрунтованими" [7, с. 78]. Водночас Н. Ю. Грицак акцентує увагу на тому, що спостерігається “невідповідність існуючих форм первинних документів, якими оформлюється процес перевезень, сучасним вимогам для побудови інформаційної системи підприємства та рівня аналітичності інформації, яка надається системою бухгалтерського обліку" [9, с. 144].

Ще одним із невирішених питань залишається неповне відшкодування перевезень пільгових категорій пасажирів автобусами міського сполучення, що призводить до недоотримання грошових коштів та негативно впливає на формування фінансових результатів.

Висновки i перспективи подальших досліджень у даному напрямі. На нашу думку, необхідно переглянути основні законодавчі документи стосовно автотранспорту, з урахуванням закордонного досвіду країн, та відобразити ці зміни у фінансовому обліку. Забезпечення автотранспорту GPSтрекерами та мобільними системами для відеоспостереження дозволить розширити внутрішньогосподарську звітність, що дуже важливо для прийняття управлінських рішень. До того ж, за допомогою цього підходу виникає можливість здійснення контролю за фактичним використанням паливомастильних матеріалів із переглядом встановлених на них норм. Також необхідне проведення реформи пільгового проїзду з метою покращення фінансового стану автотранспортних підприємств.

\section{ЛІТЕРАТУРА}

1. Мінфін [Електронний ресурс]. - Режим доступу: //https://index.minfin.com.ua/reference/people/.

2. Про транспорт : Закон України від 10.11.1994 p. № 232/94-ВР [Електронний ресурс]. - Режим доступу : http://www.rada.gov.ua.

3. Про автомобільний транспорт : Закон України від 05.04.2001 р. № 2344-III [Електронний pecypc]. - Режим доступу : http://www.rada.gov.ua.

4. Статистичні дані по галузі автомобільного транспорту - Міністерство інфраструктури України [Електронний ресурс]. - Режим доступу: 
Вісник Львівського торговельно-економічного університету. Економічні науки. № 60, 2020

https://mtu.gov.ua/content/statistichni-dani-po-galuziavtomobilnogo-transportu.html.

5. Транспорт і зв'язок України 2018: Статистичний збірник [Електронний ресурс]. - Режим доступу: http://www.ukrstat.gov.ua/ druk/publicat/ kat_u/ 2019/zb/08/zb_tr2018pdf.pdf.

6. Абрамова I. В. Стратегічні орієнтири фінансового забезпечення розвитку міського пасажирського транспорту / Абрамова I. В., Мельник Ю. С. // Вісник ЖНАЕУ. - 2017. - № 2 (62), т. 2. - С. 93-97.

7. Базилюк А. В. Бухгалтерський і податковий облік автотранспорту та перевезень : навч. посіб. / Базилюк А. В., Малишкін О. І. - К. : Центр учбової літератури, 2011. - $256 \mathrm{c.}$

8. Башинська I. О. Розумна система міського пасажирського транспорту як складова Smart City : монографія / Башинська І. О., Філіппов В. Ю. - Х. : Діса плюс, 2018. - С. 220.

9. Грицак Н. Ю. Організація бухгалтерського обліку на автотранспортному підприємстві / Грицак Н. Ю. // Міжнародний збірник наукових праць. 2011. - № 2(20). - С. 144-154.

10. Овчар П.А. Імплементація державою європейських вимог в галузі пасажирських перевезень в Україні [Електронний ресурс]. - Режим доступу : file:///C:/Users/\%D0\%9E\%D0\%BB\%

D0\%B5\%D0\%BD\%D0\%BA\%D0\%B0/Downloads/nv nau_tech_2017_275_18.pdf.

\section{REFERENCES}

1. Minfin, available at: //https://index.minfin.com.ua/reference/people/.

2. Pro transport : Zakon Ukrainy vid 10.11.1994 r. № 232/94-VR, available at: http://www.rada.gov.ua.
3. Pro avtomobil'nyj transport : Zakon Ukrainy vid 05.04.2001 r. № 2344-III, available at: http://www.rada.gov.ua.

4. Statystychni dani po haluzi avtomobil'noho transportu - Ministerstvo infrastruktury Ukrainy, available at: https://mtu.gov.ua/content/statistichni-dani-pogaluzi-avtomobilnogo-transportu.html.

5. Transport i zv'iazok Ukrainy 2018: Statystychnyj zbirnyk, available at: http://www.ukrstat.gov.ua/druk/publicat/kat_u/ 2019/zb/08/zb_tr2018pdf.pdf.

6. Abramova, I. V. and Mel'nyk, Yu. S. (2017), Stratehichni oriientyry finansovoho zabezpechennia rozvytku mis'koho pasazhyrs'koho transportu, Visnyk ZhNAEU, № 2 (62), t. 2, s. 93-97.

7. Bazyliuk, A. V. and Malyshkin, O. I. (2011), Bukhhalters'kyj i podatkovyj oblik avtotransportu ta perevezen': navch. posib., Tsentr uchbovoi literatury, K., $256 \mathrm{~s}$.

8. Bashyns'ka, I. O. and Filippov, V.Yu. (2018), Rozumna systema mis'koho pasazhyrs'koho transportu iak skladova Smart City : monohrafiia, Disa plius, Kharkiv, s. 220.

9. Hrytsak, N. Yu. (2011), Orhanizatsiia bukhhalters'koho obliku na avtotransportnomu pidpryiemstvi, Mizhnarodnyj zbirnyk naukovykh prats', № 2(20), s.144-154.

10. Ovchar, P. A. Implementatsiia derzhavoiu ievropejs'kykh vymoh $\mathrm{V}$ haluzi pasazhyrs'kykh perevezen' $\mathrm{v}$ Ukraini, available at: file://C:/Users/\%D0\%9E\%D0\%BB\%D0\%B5\%D0\%B D\%D0\%BA\%D0\%B0/Downloads/nvnau_tech_2017_2 75_18.pdf.

Стаття надійшла до редакції 08 травня 2020 року 